\title{
Technical Assistance
}
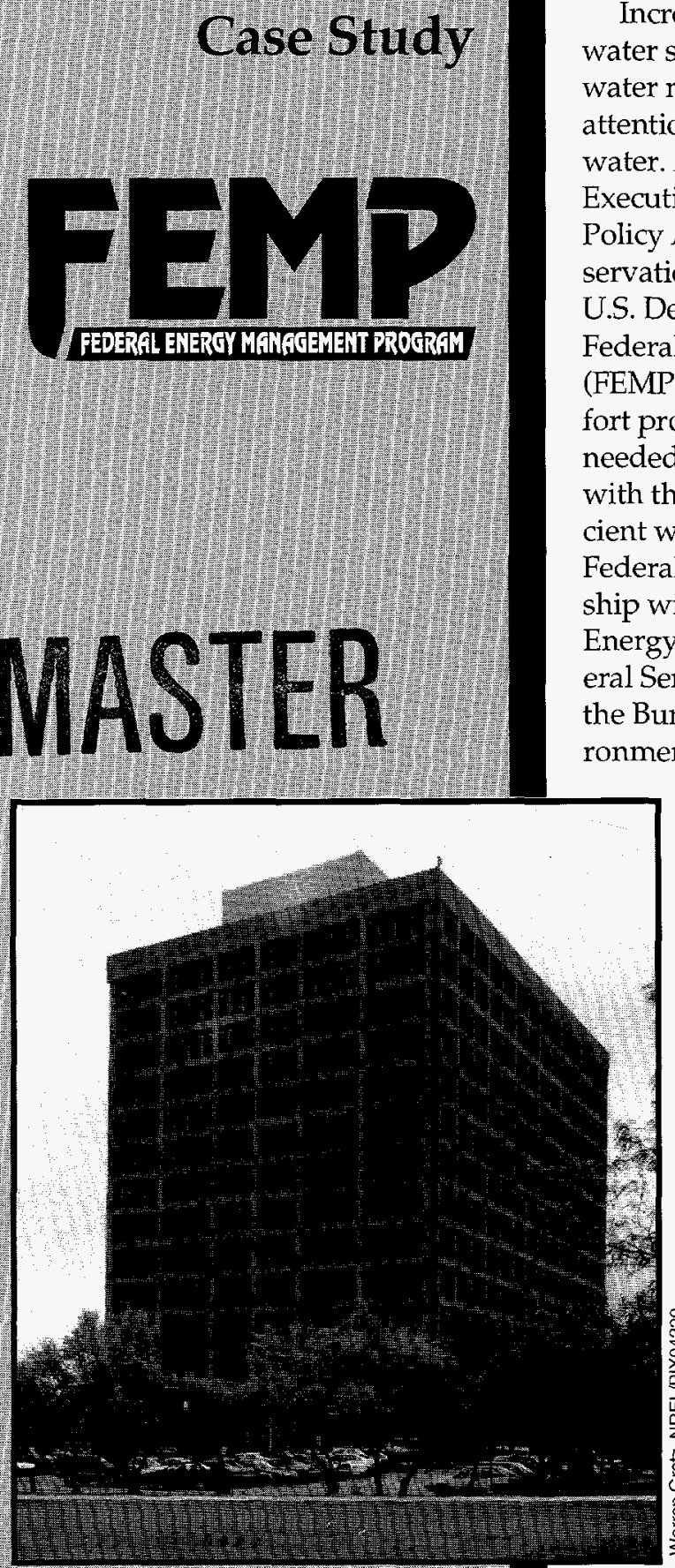

FEMP chose the 14-story Building 67 housing the Bureau of Reclamation, and an adjacent plot (foreground) at the Denver Federal Center to test the latest indoor and outdoor water conservation technologies. \section{Water Conservation at the DenfeECEIVED
Federal Center}

\section{Latest technologies save water and energy through cooperative agreement}

Increasing demands on allocated water supplies and $d$ windling fresh water resources are drawing national attention to the need for better use of water. As part of a national effort, Executive Order 12902 and the Energy Policy Act of 1992 mandated water conservation in all Federal facilities. The U.S. Department of Energy's (DOE) Federal Energy Management Program (FEMP) was tasked with leading the effort providing the technical assistance needed to identify ways to comply with the order. To apply highly efficient water use technologies in the Federal sector, FEMP formed a partnership with DOE's National Renewable Energy Laboratory (NREL); the General Services Administration (GSA); the Bureau of Reclamation; the Environmental Protection Agency (EPA); Denver Water, the local utility; and several manufacturers. The objectives of the partnership were:

- To improve energy and water efficiency in the Federal sector

- To deploy U.S. manufactured water technologies in the Federal sector

- To reduce life-cycle cost and improve reliability of Federal installations

- To establish a showcase site demonstrating technologies and operating practices of water conservation

- Ultra-low-flush (ULF) wall-hung
- To demonstrate effective government and industry partnerships.

FEMP chose the 14-story Building 67 at the Denver Federal Center for the site of the water conservation project. Building 67 houses the Bureau of Reclamation and represents a typical Federal office building. It has high visibility in the community and is located in an area of the country where new water supplies are becoming increasingly difficult to obtain.

\section{Water-conserving technologies}

FEMP issued a solicitation for the latest indoor and outdoor water use technologies. U.S. manufacturers submitted technical proposals, and FEMP selected technologies based on appropriateness to the site and building, energy and water savings potential, and transferability to other Federal buildings. The technologies included: toilets using 1.3 gallons (4.9 liters) of water per flush and ULF urinals using 0.5 gallons (1.9 liters) of water per flush provided by American Standard

- Non-water-using urinals provided by Waterless Company. (The waterless urinals were replaced by ULF urinals because they were incompatible with the building's unique plumbing system. They were successfully reinstalled at the Carl Hayden Visitors Center at Glen Canyon Dam in Arizona.)

- Sensored lavatories to reduce water use and associated electricity for water heating provided by Bradley Corporation

- Irrigation controls for a landscaped area adjacent to the building provided by WaterLink Systems, Inc.

To demonstrate the effectiveness of these technologies, all partners agreed 
Pre- and post-retrofit comparison of average weekday water use Seventh floor men's room - urinals and toilets

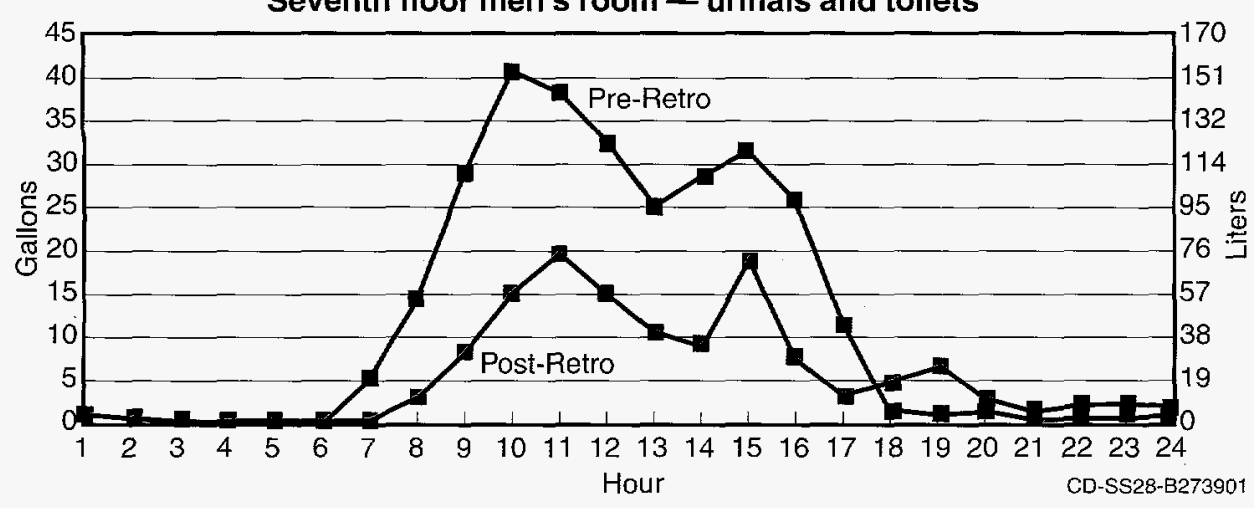

that it would be critical to determine a baseline of existing water consumption. Ultrasonic meters were installed to measure total water use in the rest rooms. These meters were chosen because the plumbing configuration inhibited in-line metering. Data from the meters were collected for approximately 10 weeks. For measuring beforeand-after results, end-use meters were installed to record 4 weeks of usage before installation of the new equipment.

\section{Plumbing retrofit results}

The average water use by toilets and urinals was 265 gallons (1003 liters) per day in the men's bathroom before the retrofits. After installing the ULF toilets and urinals, water consumption dropped to 125 gallons (473 liters) per day, representing a reduction of $50 \%$. During the course of a year, this represents a savings of more than 100,000 gallons $(379,000$ liters $)$ of water for the three retrofitted men's rest rooms. Daily water use for toilets in the retrofitted women's rest room dropped 160 gallons (605 liters) per day. This represents a savings of $36 \%$ and over the course of a year, a savings of more than 40,000 gallons (150,000 liters) of water. If all rest rooms in the building were retrofitted. with these same water-conserving technologies, the overall savings would be 1.5 million gallons ( 5.7 million liters) per year. These results do not account for savings derived from the installation. of sensored lavatories. The lavatories are being monitored to provide this information.

\section{Irrigation results}

A new irrigation control system was installed in August 1996 to control irrigation on a plot adjacent to Building 67 .
This new system uses meteorological data from the National Weather Service and calculates the correct amount of irrigation water, using the evapotranspiration (ET) rate. The ET rate accounts for water losses due to evaporation from the soil and plant transpiration. Before installation of the new system, nearly 1 million gallons ( 3.8 million liters) of water irrigated the plot per year. Based on estimates that commercial landscapes are watered at twice the rate as is needed, potential savings from this new control system are substantial. Actual water savings resulting from the new system are being monitored.

\section{Project economics}

FEMP structured the project funding as a cooperative research and development agreement (CRADA), which removed the need for standard competition and allowed for the installation of emerging technologies at no cost to the Federal government for testing the equipment. In a CRADA, manufacturers donate their technologies, and the Federal government can use only in-kind, noncapital resources. For this project, FEMP chose only a few representative rest rooms and a small landscaped area so that manufacturers could statistically test their equipment without incurring prohibitive costs.

\section{Other benefits}

Although water savings resulting from this project are substantial, there are significant related energy savings as well. These energy savings result from decreased hot water use, wastewater treatment, and pumping.

Other benefits of the project also include conservation education and awareness. With the help of all the partners involved in the CRADA, an interpretive display is being developed to showcase and demonstrate water conservation technologies. The display will communicate project results to those in the Federal sector who could employ these technologies and will raise public awareness and support.

FEMP's project at the Denver Federal Center launched its national effort to conserve water at Federal facilities. The project shows that waterconserving technologies are an option for Federal agencies to reduce both water and energy use at their facilities.

"FEMP was the driving force that got this project started," said Richard B. Bronowski, assistant buildings manager at the Denver Federal Center. FEMP will continue to work with its partners to communicate the results to other Federal agencies.

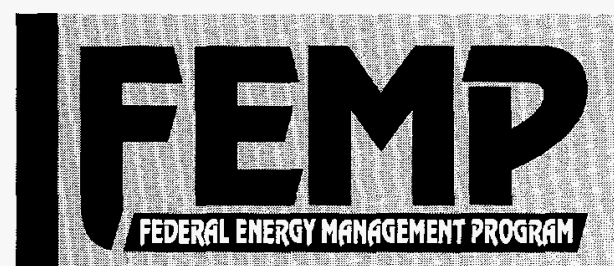

For More Information Anne Sprunt Crawley Technical Assistance Team leader DOE FEMP $(202) 586-1505$

For more information about the projed, contact:

Ashley Houston

National Renewable Energy Laboratory (303) $384-7412$

FFMP 1 Help Desk:

1-800-DOE-EREC (363-3732)

Internet: hitp//www.eren doegov/femp

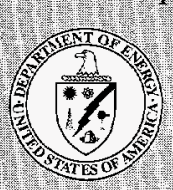

Produced for the US. Department of Energy (DOE) by the National Renewable Energy Laboratory, a DOE national laboratory

DOE/GO-10097-333

DE97000055

January 1997 


\section{DISCLAIMER}

This report was prepared as an account of work sponsored by an agency of the United States Government. Neither the United States Government nor any agency thereof, nor any of their employees, make any warranty, express or implied, or assumes any legal liability or responsibility for the accuracy, completeness, or usefulness of any information, apparatus, product, or process disclosed, or represents that its use would not infringe privately owned rights. Reference herein to any specific commercial product, process, or service by trade name, trademark, manufacturer, or otherwise does not necessarily constitute or imply its endorsement, recommendation, or favoring by the United States Government or any agency thereof. The views and opinions of authors expressed herein do not necessarily state or reflect those of the United States Government or any agency thereof. 



\section{DISCLAmier}

Portions of this document may be illegible in electronic image products. Images are produced from the best available original document. 
